\title{
Correct Management of Agroecosystem, Source of New Nutrition
}

Production of healthy food is in the focus of interest not only of developed countries, but also of those which perceive this sector as an export opportunity. Poland certainly belongs to some extent to this particular group of countries, and consequently it should cultivate this particular direction of agricultural production with care. It would seem that nothing possibly could be in the way, but something clearly is. It turns out that a serious problem is the way in which this objective is to be achieved. The idea of the so-called biodynamic agriculture ${ }^{1}$, which for years has been developed so effectively, seemed to be the only appropriate way of gaining the so-called ecological food products. However the past years have shown that this presumption was wrong. Effects achieved in biodynamic production are not only unsatisfactory from the economic viewpoint, but also with respect to quality. Biodynamic products as a rule tend to look so unappetising that inter alia for this reason a market success is highly unlikely to be achieved. Moreover, there is also the everlasting problem of research and certification of this food and of farms where they come from. Despite such a great number of various agreements, even those on an international scale, the process has not been fully worked out, and consequently not sufficiently reliable. It is not reliable inter alia because tests for the contents of heavy metals are so expensive that they cannot be performed for all batches of agricultural production. A separate problem is the attestation of farms, which frequently are transformed into biodynamic ones at a really express pace, practically form one day to another. However, not all elements of the environment can be transformed at such a pace. This concerns inter alia also the soil. It is impossible to change within a single day properties of soil on which up to now there was intense cultivation, and following an administrative decision healthy food is to be produced there, and all of a sudden the same soil is expected to have "biodynamic" values ${ }^{2}$. Attestation of such a farm

\footnotetext{
1 M. GóRny, Biodynamiczna uprawa roślin na działce, Wydawnictwo Towarzystwa Psychotronicznego, Warszawa 1984, s. 200.

2 A. S. Pullin, Biologiczne podstawy ochrony przyrody, Wydawnictwo PWN, Warszawa 2005, s. 392.
} 
focuses on the method of planned production, without any regard whatsoever to the so-called production past. It turns out, however, that this past and the way in which agricultural production is executed in the neighbouring farms, become a crucial problem in production of healthy food. This is intensified even further by the already mentioned economic and the quality of production as regards its appearance. All those problems incline to consider the sense of the entire idea. Production of healthy food is certainly future oriented undertaking, willingly supported on the area of the European Union, yet it seems necessary to work out a new production system. A system which would not only be based on biodynamic production, but which would also take into account all other achievements of contemporary sciences comprised by broadly understood agroecology $y^{3}$. The importance of this problem increases with intensified degradation of the natural environment. This concerns not only agricultural production itself (fertilizers, plant protection agents), but also industrial and communal production, which affects directly or indirectly the quality of agricultural production ${ }^{4}$. Propagation of the concept of healthy food has its broad scientific justification.

The latest research of scientists has shown that it is not air pollution which poses for us the greatest source of danger. Potable water and cigarettes is not the major threat either. It turns out that our food is the greatest threat of all. The way that we consume and where our food comes from, the food that we buy is a determinant factor for the degree of accumulation of harmful substances in our organisms. In this process a crucial role is played by plants, which are the main components in our diet as regards percentage share ${ }^{5}$. Plants play an extremely important role both in the diet and in the natural environment. With the use of chlorophyll, which is contained in their leaves, they may produce simple monosaccharides, such as for example grape sugar (glucose) and fruit sugar (fructose). In this process they release oxygen and emit it into the environment. From those monosaccharides plants produce numerous compound substances, such as starch, cellulose, proteins, fats and organic acids. To be able to produce those substances plants need not only solar light, carbon dioxide and water but also inorganic salts. People and animals have no such properties and consequently their existence is irreversibly connected with plants as a source of food and consequently also energy.

In addition plants fulfil several very important functions, also for the natural environment. They are able not only to help directly improve the air quality, but may also affect favourably the course of several other processes, such as soil erosion, regulation of water circulation or improvement of local climate ${ }^{6}$.

3 K. Falı́́sKa, Ekologia roślin, Wydawnictwo PWN, Warszawa 2004, s. 511.

4 L. M. Thompson, F. R. Troen, Soi land soil fertility, McGraw-Hill 1987, s. 516.

5 J. B. Harborne, Ekologia biochemiczna, Wydawnictwo PWN, Warszawa 1997, s. 351.

6 P. A. AlLEN, Procesy ksztaltujace powierzchnię Ziemi, Wydawnictwo PWN, Warszawa 2000, s. 475. 
Unfortunately due to human activity cultivated plants are to an increasing degree polluted by various substances that lead to their qualitative degradation. In many cases the change in chemical composition of plants is the direct cause for other adverse phenomena, which include inter alia a fall in plant mass. This phenomenon is particularly well known to farmers, who introduce significant quantities of nitrogenous fertilisers to achieve the maximum plant production mass, and through that lead to a dangerous phenomenon of soil overfertilisation? The indirect fall in the plant production mass very frequently becomes a reason for bankruptcies of many producers. If such changes start taking place in the chemical composition of plants, also their quality would be automatically considerably to be of inferior quality.

Apart from industrial pollution factors that cause pollution of plant production, also the incorrectly executed chemicalisation ${ }^{8}$ process has its share in the problem. Apart from profits that chemicalisation may bring, increasingly frequently observed are phenomena that lead to gradual degradation of the soil environment. Intensive fertilisation has a considerable share in this process. It is generally known that without appropriate fertilization correct growth of a plant is practically impossible. However, the possibility of having soil simultaneously overfertilised, along with all the resultant consequences for cultivated plants, is still to an insufficient extent taken into consideration. The latest studies in this sphere have proven that for cultivated soils and plants much more dangerous is its excessive fertilisation than its deficiency, even if it comes to such indispensable elements, as: nitrogen, phosphorus or potassium. This is directly connected with the fact that it is much easier to affect the soil environment at the moment when specified deficiencies are detected, than the other way around. For this reason it is not maximum, but exclusively optimum quantities of $\mathrm{N}, \mathrm{P}, \mathrm{K}, \mathrm{Ca}$ that should be introduced to the soil to prevent disturbing the biological balance, and hence to prevent decreasing its fertility.

A particular role in the fertilisation process is played by nitrates. Plants process nitrates, and use nitrogen for production of proteins, chlorophyll and other substances. Nitrogenous fertilisation is favourable for considerable increase in harvests and bigger content of protein in plants. However especially in the event of this element there is a possibility of exceeding permissible values. Nitrites transformed into nitrates over a very short time may become a highly toxic substance. This results from the fact that plants are unable to process larger

\footnotetext{
A. Kabata-Pendias, H. Pendias, Biogeochemia pierwiastków śladowych, Wydawnictwo PWN, 1993, s. 363.

8 T. Lityński, H. Jurkowska, Żyzność gleby i odżywianie się roślin, Wydawnictwo PWN, Warszawa 1982, s. 643.

9 Red. S. ZawadZKI, Gleboznawstwo, Wydawnictwo PWRiL, Warszawa 1999, s. 559.
} 
quantities of nitrates. Nitrates accumulated in a plant pose a severe threat for health of humans who consume plant products coming from such production ${ }^{10}$. It is the nitrates which along with other substances contained in food pose the greatest threat for a human owing to the possibility of initiating carcinogenic processes. Nitrates themselves also may become a pathogenic factor. They may cause, inter alia, an illness called cyanosis, which attacks in infants and children below three years of age. Several fatalities were recorded for infants because of excessive levels of nitrates in food consumed by them. Consuming foods that pose a risk to life and health, which contain a considerable content of those substances, have inclined the World Health Organisation (WHO) to take up the problem of nitrites. This organisation recommended that first of all the contents of nitrates should be reduced in potable water. At the same occasion determined were quantity thresholds for nitrogenous fertilisers used in agriculture. Unfortunately results of the last WHO report have proven that guidelines of that organisation would remain only on paper. The report shows that at present many regions worldwide have serious problems with maintaining supplies of potable water with a level of nitrates lower than $50 \mathrm{mg}$ nitrates per one litre of water. The situation is similar for tests of nitrate contents in edible plants. They have shown clearly that the increase in nitrate contents in cultivated plants is directly in proportion to the intensity of applied fertilisation.

Threats for consumers coming from accumulated nitrates in plants varies. It depends inter alia on which part of the plant is edible. Nitrogen is not evenly accumulated in all parts of a plant. It is mainly stored in shoots and petioles of leaves ${ }^{11}$. For this reason a relatively low level of nitrates may be found in grains, fruit, beans, cucumbers and tomatoes (because they have no leaf petiole or shoots). Their biggest quantity, on the other hand, may be found in spinach, radish, carrots, or in sugar beet.

Also the insolation level has a significant impact on the nitrogen contents. The lower this level the more nitrates may be expected in those plants. Particularly on overcast winter days vegetables cultivated in glasshouses are highly endangered. For this reason in that part of the year it is recommended to limit the consumption of lettuce, which belongs to the group of vegetables which are most exposed to accumulation of nitrates. Calculations have shown that in the winter period the increase in the content of nitrates in lettuce may even be tenfold. An even bigger scale of fluctuations for nitrate contents is recorded for sugar beet.

Statistical analyses show that on average $70 \mathrm{mg}$ nitrates are absorbed by our organism in our daily nutrition (this concerns exclusively the consumption of vegetables). However, it ought to be borne in mind that vegetables are not the

10 C.H. Walker, S.P. Hopkin, R.M. Sibly, D.B. Peakall, Podstawy ekotoksykologii, Wydawnictwo PWN, Warszawa 2002, s. 371. 
only source. Nitrates are also present in potable water and in meat. According to recommendations of WHO our nourishment should not contain more than $250 \mathrm{mg}$ nitrates daily. Naturally those values are only related to adults. For infants and children under 7 years of age the limiting value for daily consumption should be much lower. Products particularly exposed to increased nitrate levels are vegetable juices. The most dangerous in this group is juice of sugar beet, sauerkraut and a juice of all vegetables. For children under 7 years of age also carrot juice may prove to be particularly dangerous. The rather popular and liked tomato juice is considered to be the safest in this scope.

Exceeded nitrate levels affect people in a direct way, but also indirectly plants, and in such a way reduce their nutritional value. A good example are potatoes, the nutritional value and content of which, along with the content of vitamin $\mathrm{C}$ falls as nitrate quantities grow. Also their value is reduced as regards their appearance and water content. Overfertilised potatoes may be frequently identified by the fact that they are boiled with some difficulty. For the farmers it should be of importance that increased nitrate levels cause difficulties in their storage. The border between the indispensable nitrate contents and their excessive level is very thin. Potatoes in which the content of $100 \mathrm{mg} / \mathrm{kg}$ are as a rule excellent in quality. Completely different are potatoes with over $300 \mathrm{mg} / \mathrm{kg}$ nitrates. In extreme cases overfertilisation may even destroy the entire plantation and lead to degradation of the entire agroecosystem ${ }^{12}$. A certain paradox in such a situation is the fact that a lot of farmers still does not perceive actual dangers that nitrogenous overfertilisation brings. Side effects of this uncontrolled process, which is caused only by endeavour at achieving at all cost the maximum production increase, are a typical example for disregarding the importance of the natural environment, which we are all living in, and on which in the end we are completely dependent.

By applying certain elements of biodynamic food production it is possible to eliminate clearly some chemical threats, coming inter alia from the incorrectly executed chemicalisation process which had been implemented earlier. In such a way it is possible to reduce the contents of some noxious substances even by almost a half. This process is based on the phenomenon which is connected with the so-called diurnal rhythm, which affects fluctuations of nitrate levels in plants. Studies have shown that plants contain more nitrates during the night than an day time. The cause is the fact that plants process nitrogen only when there is light. To allow best minimising of the nitrate quantities, plants should not be harvested in early hours of the morning. If for example parsley is harvested early in the

${ }_{11}$ S.M. Ross, Toxic metals In soil-plant systems; John Wiley \& Sons, Chichester 1994, s.469.

12 Z.T. DĄBRowsKi, Podstawy odporności roślin na szkodniki, Wydawnictwo PWRiL, Warszawa 1988 , s. 260. 
morning, nitrates absorbed during the night would still be in it unprocessed. A completely different consumption value would be recorded for parley collected late in the afternoon.

In laboratories certain species of vegetables have already been determined which accumulate exceptionally small quantities of nitrates. In some shops of the European Unions they are provided with special markings to allow making an appropriate choice. Unfortunately in Poland we are still unable to afford such a luxury. For the time being consumers in our country are only left with the other way of decreasing the threat, by their very accurate washing. This concerns particularly young vegetables, which should also be boiled or steamed. This is of particular importance as nitrates are well soluble in water. For this reason their considerable quantities may be eliminated in boiling or steaming.

It cannot be ruled out, however, that we would keep having nitrates in our food more and more frequently. One of the reasons for such a situation is the level of soil fertility in Poland. Because of this the share of fertilisation in the general chemicalisation balance of our agriculture is more or less at the level of $60 \%$, and the remaining $40 \%$ - pesticides. Pesticides are the second source of pollution for cultivated plants, which is an effect of incorrect chemicalisation of agriculture ${ }^{13}$. Threat coming from pesticides is connected with the fact that none of them is fully neutral for agrocenosis. Especially dangerous among them as such substances as mercuric organic compounds, chlorinated hydrocarbons, phosphoric organic compounds or carbamates. Their uncontrolled use is a source of serious degradation of the soil environment, and causes a significant increase of substances that are very dangerous for human health.

Both in the event of pesticides and food product contamination resulting from direct industrial operation, our knowledge gained from agroecology and correct management of the agroecosystem may in a critical way affect the quality of plant production. It seems that this is presently the most appropriate course for activity, which to a certain extent may resemble a process from the recent past, which was based on introducing to the agricultural culture the so-called integrated plant protection methods.

${ }_{13}$ GUS, Użytkowanie gruntów, powierzchnia zasiewów i poglowie zwierząt gospodarskich w $2004 \mathrm{r}$. Informacje i opracowania statystyczne, Zakład Wydawnictw Statystycznych, Warszawa 2004, s. 79. 


\section{STRESZCZENIE}

Produkcja zdrowej żywności w Polsce ma już dość długą tradycję. Naukowe podstawy jej sięgają drugiej połowy lat osiemdziesiątych, kiedy to na Wydziale Żywienia Człowieka SGGW-AR w ramach wykładów z Ekologii, został uruchomiony pierwszy blok edukacyjny w zakresie produkcji biodynamicznej roślin. Zajęcia te miały wówczas, nie tylko wymiar edukacyjny, ale również czysto polityczny. W okresie tym w Polsce, istniał jedynie jeden słuszny kierunek produkcji rolniczej, opierający się w swoich załozeniach, bynajmniej nie na produkcji ekologicznej. Zwolennicy ekologicznego podejścia do produkcji roślinnej, byli traktowani, jako groźni dywersanci, którzy chcą zburzyć istniejący „porządek naukowy" ukształtowany wokół ówczesnych zasad uprawy roli i roślin obowiązujący od lat w naszym kraju. Z tego też powodu rolnictwo tzw. alternatywne, nie mogło się prawidłowo rozwijać (pomimo tego nawet, że było stosunkowo wielu chętnych rolników do jego wprowadzania). Jedną z barier jego rozwoju oprócz czynników politycznych, był ogólny brak wiedzy w zakresie rolnictwa ekologicznego. Bariery tej, nie można było pokonać bez rozwiniętego zaplecza naukowego i edukacyjnego na uczelniach rolniczych. Fakt ten w istotny sposób ograniczył rozwój wszelkich form produkcji zdrowej żywności w naszym kraju.

$\mathrm{Z}$ perspektywy dzisiejszego dnia, problemy przed którymi stali zwolennicy produkcji zdrowej żywności, wydają się wręcz śmieszne. Wraz z procesem transformacji ustrojowej oraz wejściem Polski do Unii Europejskiej, wszelkie ograniczenia w tym również i polityczne, przestały istnieć. Na pierwszy plan natomiast wysunęły się problemy merytoryczne, dotyczące produkcji zdrowej żywności. Autor w artykule Pt. Prawidłowe zarządzanie agroekosystemem źródłem zdrowej żywności, porusza właśnie ten zakres problematyki wokół merytorycznych podstaw produkcji tej żywności. Przez wiele lat skutecznie rozwijana idea tzw. rolnictwa biodynamicznego wydawała się jedyną właściwą drogą do uzyskania tzw. zdrowej żywności. Ostatnie lata dowodzą jednak, że nie jest to właściwa droga. Efekty uzyskane w wyniku produkcji biodynamicznej są nie tylko, nie zadawalające z punktu widzenia ekonomicznego, ale również i jakościowego. Na to wszystko, nakłada się odwieczny problem badań i certyfikacji tej żywności oraz gospodarstw rolnych z których pochodzi produkcja. Proces, który pomimo wielu uzgodnień przeprowadzonych nawet w skali, międzynarodowej, nie jest jednak do końca dopracowany, a zarazem wystarczająco wiarygodny. Osobnym problemem jest sama atestacja gospodarstw rolnych, które najczęściej przemieniają się w biodynamiczne $w$ iście ekspresowym tempie, praktycznie $z$ dnia na dzień.

Produkcja zdrowej żywności jest z pewnością przedsięwzięciem przyszłościowym, chętnie wspieranym na terenie Unii, jednakże wydaje się koniecznym wypracowanie nowego systemu produkcji. Systemu, który opierałby się nie tylko na produkcji biodynamicznej, ale również uwzględniał wszystkie inne zdobycze 
współczesnych nauk, składające się na szeroko rozumianą agroekologię Jest to tym ważniejsze, im z poważniejszą degradacją środowiska przyrodniczego i jego zasobów mamy do czynienia.

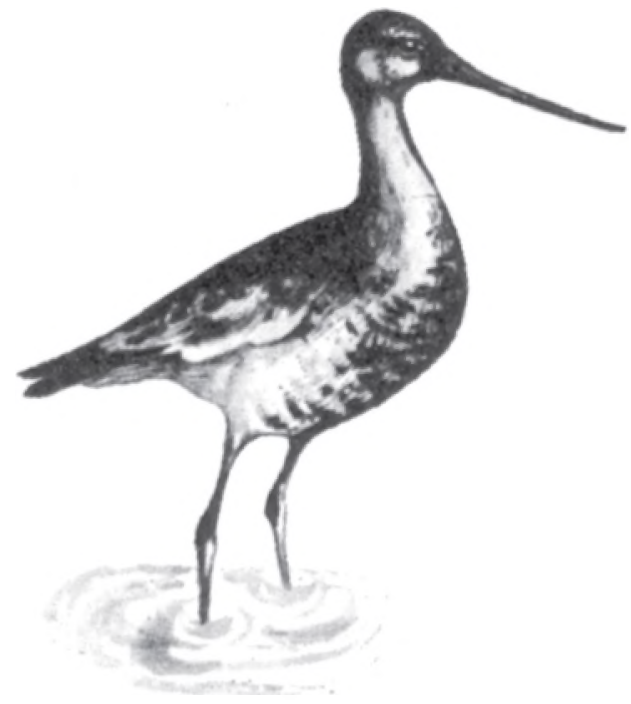

Rycyk 